\title{
KEPEMIMPINAN TRANSFORMASIONAL DI SEKOLAH-SEKOLAH MUHAMMADIYAH
}

\author{
Oleh: \\ Sentot Imam Wahjono \\ Universitas Muhammadiyah Surabaya \\ E-mail : totim27@yahoo.com
}

\begin{abstract}
To avoid the pattern of laissez-faire leadership at the head of Muhammadiyah schools required the application of trans-formational leadership pattern. This is supported by a study evaluating the effect of Authentic Transformational Leader-ship behaviors of Emotional Intelligence by intervening variable: Value congruence, Trust and Respect for teachers and employees in Muhammadiyah schools. The sample used in this study were 66 employees and 125 teachers. The results show that the behavior Authentic Transformational Leadership have a significant influence on Emotional Intelligence directly. Significant influence is also shown intervening variables: value congruence (posi-tive), Trust (negative) and Respect (negative).
\end{abstract}

Keywords: authentic transformational leadership, emotional intelligence, value congruence, trust, reverence.

\section{PENDAHULUAN}

Persoalan yang dihadapi oleh sebagian besar sekolah Muhammadiyah pada saat ini adalah mencari figur pemimpin. Sekolah-sekolah Muhammadiyah seperti pada umumnya sekolah swasta, mengalami kesulitan mencari pola pemimpin yang benar-benar mampu menjalankan tugasnya dengan baik. Bahkan terkadang sulit membedakan antara pola kepemimpinan organisasi sekolah dengan organisasi persyarikatan Muhammadiyah. Karena pada prakteknya dalam mengelola sekolah, pola kepemimpinannya hampir sama dengan megelola organisasi persyarikatan Muhammadiyah.

Adanya budaya organisasi yang kurang sehat ini mengakibatkan kecenderungan sekolah menjadi tidak berdaya. Sebab, kepemimpinan dalam dalam sekolah tidak dapat disamakan dengan kepemimpinan dalam organisasi persyarikatan. Kepemimpinan di sekolah lebih betsifat "birokratis" ketimbang di organisasi persyarikatan. Dengan demikian, pencampuradukan budaya kepemimpinan organisasi persyarikatan ke dalam sekolah mengakibatkan semakin tidak efektifnya kepemimpinan sekolah. Kecenderungan budaya kepemimpinan organisasi persyarikatan itu tanpak dalam kepemimpinan di sekolah Muhammadiyah, yaitu berkembangnya pola kepemimpinan laissez-faire. Gaya kepemimpinan seperti ini memberikan kebebasan kepada personel- personelnya secara leluasa dengan tidak disertai daya kontrol yang kuat. Sehingga hubungan-hubungan yang semestinya menambah kemitraan akhirnya menjadi kurang baik (Mujtahid, 2011).

Kontribusi persyarikatan Muhammadiyah dalam pembangunan pendidikan sangatlah menonjol. Perkembangan kiprah Muhammadiyah di bidang pendidikan bahkan dimulai sebelum Indonesia merdeka. Sejarah mencatat pada tahun 1932 Muhammadiyah sudah memiliki 103 Volkschool, 47 standaardschool, 69 Hollands Inlandse School (HIS), dan 25 Schakelsschool, yaitu sekolah lima tahun yang akan menyambung ke MULO (Meer Uitgebreid Lager Onderwijs) yang setingkat dengan SMP saat ini, bagi murid tamatan vervolgshool atau standaardschool kelas V (Suara Muhammadiyah, Edisi 14 2004).

Bila dibandingkan dengan kondisi sekarang jumlah tersebut mengalami peningkatan yang signifikan. Banyaknya jumlah sekolah Muhammadiyah yang tersebar merata di seluruh Indonesia sampai dengan tahun 2005 jumlah sekolah Muhammadiyah adalah 13.803, terdiri dari 9.281 SD sederajat kebawah, 3.426 SMP sederajat, 929 SMA sederajat dan 167 Perguruan Tinggi (Suyanto, 2006: 5). Beberapa diantaranya telah tumbuh menjadi sekolah unggul dan banyak diantaranya menggeliat berikhtiar keras dan berlomba untuk menjadi sekolah unggul. 
Perlombaan untuk menjadi sekolah unggul itu dikarenakan oleh pergeseran orientasi pendidikan di lingkungan Muhammadiyah. Penyelenggaraan pendidikan Muhammadiyah yang semula dimaksudkan untuk membebaskan umat dari kebodohan berkembang menjadi wilayah pemberdayaan yang ditujukan untuk meningkatkan kualitas keimanan dan kesejahteraan. Pergeseran orientasi ini diperkuat dengan pemberlakuan Undangundang nomor 20 tahun 2003 tentang Sistem Pendidikan Nasional.

Keunggulan sekolah bukanlah terletak pada input unggul, proses unggul dan melahirkan output unggul, melainkan terletak pada keunggulan proses yang menuntut tersedianya secara maksimal segala sesuatu yang menyangkut proses belajar mengajar itu sendiri (Yusuf, 2004: 4). Untuk itulah diperlukan sumber daya manusia yang mampu menyediakan secara maksimal proses belajar mengajar yang unggul.

Visi Pendidikan Nasional mengarahkan terciptanya Insan Indonesia Cerdas dan Kompetitif sebagai Visi 2025 (Sudibyo, 2006: 2). Yang dimaksud dengan Insan yang Cerdas dan Kompetitif adalah cerdas Spiritual, cerdas Emosional dan Sosial, cerdas Intelektual serta cerdas Kinestetik. Pembentukan insan cerdas dan kompetitif itu bisa terjadi di sekolah dengan pemimpin sekolah yang telah mempunyai kriteria cerdas dan kompetitif. Kepala sekolah sebagai agen pembentuk insan cerdas dan kompetitif diharapkan sudah mempunyai dan mampu mempraktekkan kecerdasan spiritual, kinestetik, sosial, intelektual dan kecerdasan emosional.

Dua pernyataan tokoh pendidikan Muhammadiyah diatas menyiratkan pentingnya sumber daya manusia di bidang pendidikan yang berkualifikasi tinggi yang mampu menggerakkan proses belajar mengajar di sekolah sehingga mampu membentuk insan cerdas dan kompetitif. Peranan pemimpin sekolah dalam mengelola sumber daya manusia di sekolah sangat diperlukan. Adakah hubungan keberhasilan kepemimpinan dengan moral atau agama?

Kepemimpinan dalam sebuah lembaga pendidikan berbasis keagamaan seperti Muhammadiyah merupakan fenomena yang menarik untuk diamati. Kurikulum yang diberikan pada sekolah-sekolah Muhammadiyah mengandung pelajaran agama Islam lebih banyak daripada pelajaran di sekolah-sekolah negeri (state own school). Matapelajaran yang dimasukkan ke dalam kurikulum sekolah-sekolah Muhammadiyah sebagai kandungan lokal meliputi mata pelajaran Aqidah, Bahasa Arab, Ibadah, al-Qur'an dan Tafsir, Akhlak dan Kemuhammadiyahan yang penuh dengan ajaran nilai-nilai moral, terutama nilai agama Islam. Masih ditambah dengan penyelipan nilai-nilai agama Islam ke dalam setiap pelajaran umum (Sains, Matematika, Bahasa Indonesia, Bahasa Inggris, Bahasa Jawa, PKPS, dll.). Nilai-nilai agama tersebut merupakan fondasi dari Kecerdasan Emosional (Agustian, 2001 :15).

Peran lembaga pendidikan Muhammadiyah sekarang ini sedang diuji. Hal ini ditunjukkan dengan semakin besarnya antusiasme masyarakat untuk memasukkan anaknya ke sekolah yang berbasis agama. Sehingga persepsi sekolah agama sebagai lembaga pendidikan kelas dua sekarang mulai sirna. Bahkan di beberapa daerah di kota Surabaya, jumlah murid sekolah-sekolah Muhammadiyah terhitung lebih banyak dari sekolah-sekolah negeri (sebagai contoh SD Muhammadiyah 4 mempunyai 7 kelas paralel, SMPM 5 mempunyai 7 kelas paralel, SMAM 2 mempunyai 10 kelas paralel; data diambil dari Majlis Dikdasmen Pimpinan Daerah Muhammadiyah Surabaya untuk tahun pelajaran 2005/2006). Hal ini menunjukkan bahwa kepercayaan masyarakat terhadap sekolah-sekolah Muhammadiyah pada level yang tinggi, sekaligus merupakan sebuah peluang untuk menunjukkan kesiapan dan kemampuan sekolah-sekolah Muhammadiyah untuk menjawab kepercayaan masyarakat tersebut secara konsisten. Kehadiran sekolah-sekolah yang berbasis agama memang menjadi trend baru bagi masyarakat yang sedang mengalami transisi. Harapan terbesar para orang tua menyekolahkan anaknya di sekolah berbasis agama adalah untuk membentengi anak-anak mereka dari segala macam perilaku menyimpang seperti narkoba, pergaulan bebas dan kehidupan abnormal lainnya.

Nilai-nilai moral dalam sekolah-sekolah yang berbasis agama diajarkan untuk menyiapkan anakanak dalam menghadapi permasalahan hidup yang semakin kompleks. Mereka tidak hanya dididik untuk mengasah intelektualitasnya saja, namun juga digembleng dengan ajaran-ajaran moral. Bermacammacam nilai moral yang terkandung dalam Al Qur'an dan Hadist diajarkan sebagai pembinaan mental para siswa. Nilai-nilai moral (akhlak alkarimah) itulah yang menjadi embrio dari salah satu kecerdasaan, yang saat ini sedang menjadi pusat penelitian para ahli yang ingin meneliti tentang faktor penting yang mendukung kesuksesan para pemimpin, yakni kecerdasan emosional (Agustian, 2001: 200). 
Sedangkan Goleman et al (2002 : 212) menemukan bahwa kecerdasan emosional merupakan key succes factor bagi seseorang untuk sukses dalam kehidupan.

Pemimpin dalam organisasi publik seperti sekolah-sekolah Muham-madiyah (dalam hal ini kepala sekolah), saat ini diuji untuk mewujudkan tujuan dari organisasi yang dipimpinnya. Para siswa tidak hanya diproses untuk pandai intelektualitasnya, namun juga harus pandai emosi dan hatinya. Para guru dan karyawan memiliki peran dalam mempengaruhi dan mengarahkan anak didiknya, karena mereka berhubungan langsung dengan para siswa. Kepekaan dan kecerdasan emosional para guru dan karyawan diharapkan mampu meresap ke sanubari para siswa, sehingga timbul adanya peniruan (duplikasi) dan membentuk standar yang tinggi bagi perilaku siswa. Kepekaan dan kecerdasan emosional para guru dan karyawan berasal dari kecerdasan emosional kepemimpinan transformasional yang otentik melalui loop terbuka sistem limbuk (Goleman et al. $2002: 8$ ).

Peran pemimpin dalam suatu organisasi manapun sangat penting dan strategis. Menurut Goleman I(2002 : 9) pemimpin mempunyai daya maksimal untuk mempermainkan emosi setiap orang. Jika emosi orang-orang didorong ke arah antusiasme, kinerja akan meningkat. Jika emosi orang-orang didorong ke arah kebencian dan kecemasan, kinerja akan merosot. Artinya jika pemimpin menggerakkan emosi secara positif, ia akan memancing keluar sisi terbaik dari setiap orang.

Kepala sekolah memiliki peran yang sangat strategis untuk mencapai harapan para orangtua / wali murid khususnya dan masyarakat pada umumnya, sekaligus mencapai tujuan dari sekolah yang dipimpinnya. Salah satu cara untuk mengembangkan organisasi yang dipimpinnya, yakni melalui pengembangan kepemimpinannya. Efektifitas kepemimpinan kepala sekolah sangat menentukan keberhasilan sekolah yang dipimpinnya dalam mencapai tujuannya. Untuk itu perlu diteliti lebih jauh tentang pengaruh kepemimpinan transformasional yang otentik terhadap kecerdasan emosional guru dan karyawan sekolah Muhammadiyah di Surabaya.

Penelitian ini dimaksudkan untuk melihat hubungan antara kepemimpinan (Authentic Transformational Leadership/ATL) dengan Kecerdasan Emosional (EQ) dengan 3 varibale intervening berupa Kesamaan Nilai, Rasa Kagum dan Kepercayaan pada pemimpin di sekolah-sekolah Muhammadiyah.

\section{Kepemimpinan Transformasional yang Otentik}

Awal istilah kepemimpinan transformasional yang otentik bermula dari kritikan tajam tentang kedudukan moralitas dalam kepemimpinan transformasional, terutama oleh para liberalis, "grass root" theorist, dan para konsultan pengembangan organisasi. Bass dan Steidmeier (1998) menegaskan bahwa kepemimpinan transformasional yang sesungguhnya harus dibangun dari dasar / fondasi moral. Hal senada juga dikemukakan oleh Burn (1978 dalam Bass dan Steidmeier 1998), yang menyatakan bahwa kepemimpinan transformasional yang otentik harus bersandar pada dasar nilai yang sah (legitimate value).

Menurut (Bass, 1985; 1990; Bass \& Avolio, 1990) kepemimpinan transformasional yang otentik mengandung empat komponen yakni: (1). Idealized Influence, (2). Inspirational Motivation (3). Intel-lectual stimulation (4). Individualized Consideration. Shamir, House dan Arthur (1993), Conger \& Kanungo (1988) meletakkan komponen yang sama pada kategori charismatic leadership (kepemimpinan karismatik). Para pengikut memihak pada aspirasi para pemimpin-pemimpin karismatik dan berusaha untuk menyamai para pemimpin tersebut.

Idealized influence dari pemimpin adalah memimpikan, yakin dan membentuk standar yang tinggi usaha penyamaannya. Inspirational motivation akan menjadi bekal para pengikut dalam menghadapi tantangan untuk mencapai tujuan. Intellectual stimulation dari kepemimpinan transformasional membantu para pengikut untuk menjawab asumsi dan untuk membangkitkan solusi yang lebih kreatif terhadap masalah-masalah yang dihadapi. Individualized consideration dari kepemimpinan transformasional memperlakukan masing-masing bawahan sebagai individu dan mendampingi, memonitor dan menumbuhkan peluang. Kepemimpinan transformasional yang otentik akan ditandai dengan standar moral dan etika yang tinggi dari masing-masing komponen di atas.

Bass (dalam Bass dan Steidmeier, 1998) memberi ciri kepada pemimpin yang menjalankan "Kepemimpinan Transformasional Yang Otentik" sebagai berikut: "Para pemimpin transformasional yang sesungguhnya yakni ketika mereka memberikan kesadaran tentang apa itu benar, baik, indah, ketika mereka membantu meninggikan kebutuhan dari para bawahan dalam mencapai apa yang diinginkan dan dalam mencapai aktualisasi, para pemimpin membantu dalam mencapai tingkat kedewasaan moral yang lebih tinggi dan ketika para pemimpin itu mampu 
menggerakkan para bawahannya untuk melepaskan kepentingan diri mereka sendiri untuk kebaikan group, organisasi, maupun masyarakat".

Literatur tentang kepemimpinan transformasional yang otentik terkait dengan literatur yang telah ada sejak masa lampau yang berhubungan dengan karakter moral dan kebaikan, seperti ditunjukkan oleh ajaran Sokrates dan Confusius. Ajaran-ajaran moral ini merupakan fondasi dari kecerdasan emosioanal (Agustian,2001:50). Siswanto (2005), menemukan bahwa kepemimpinan transformasional di Madrasah yang berbasis pondok pesantren modern memiliki nilai yang tinggi pada 4 komponen yang membentuk kepemimpinan transformasional. Kezar (2004) dan Hsu et al. (2005) juga menemukan hal yang serupa untuk lembaga-lembaga keagamaan yang berlokasi di Taiwan. Hal ini berarti sama dengan pendapat Bass (1985), bahwa kepemimpinan transformasional yang otentik ditandai dengan tingginya nilai dari keempat komponen yang membentuk kepemimpinan transformasional yang otentik.

\section{Kecerdasan Emosional}

Definisi yang luas tentang kecerdasan emosional yakni kemampuan untuk memonitor perasaan dan emosi dirinya dan orang lain untuk membedakan antara keduanya, dan menggunakan informasi tersebut untuk mengarahkan pikiran dan tindakan seseorang (Salovey \& Mayer, 1990). Definisi ini menekankan pada sejumlah perbedaan tetapi saling terkait. Kecerdasan emosional itu sendiri dapat dikonsep secara relatif sebagai suatu keasadaran individu terhadap emosinya sendiri dan kemampuan untuk mengekspresikan emosi-emosi tersebut, untuk persepsi-persepsi individual dan kesadaran dari emosi-emosi tersebut diekspresikan oleh pihak lain, untuk pengaturan emosi baik untuk diri sendiri atau orang lain, dan untuk menggunakan emosi tersebut.

Goleman $(1995 ; 1998)$ berpendapat bahwa keseimbangan dan manajemen emosi kita akan menentukan seberapa cerdas kita akan bertindak dan seberapa sukses kita dalam hidup. Model yang dikemukakan oleh Goleman (1995) tentang kecerdasan emosional sangat luas. Dia berpendapat bahwa sebagian besar kemampuan manusia termasuk dalam konsepsi kecerdasan emosional, yakni: frustasi, toleransi, menunda kegembiraan, motivasi, bersemangat, tekun, mengontrol gerak hati, pengaturan suasana hati, empati, penyesuaian diri dengan orang lain, pengharapan dan optimis. Komponen yang termasuk dalam variabel kecerdasan emosional ada 7 (Yong, 2003). Tujuh komponen tersebut diukur dengan "The Yong EQ Inventory", yakni kuesioner self report yang terdiri atas 28 item yang mengukur 7 dimensi dari kecerdasan emosional. Ketujuh dimensi tersebut dipilih berdasarkan studi literatur dari konsep EQ Inventory, misalnya Baron dan Parker (2000), Salovey \& Mayer (1990). Ketujuh dimensi tersebut meliputi: Intrapersonal skills, yakni keahlian seperti kemampuan mengenali emosinya sendiri dan membentuk model diri sendiri yang akurat dan realistik, serta mampu menggunakan model tersebut untuk dioperasikan secara efektif dalam kehidupan. Interpesonal skills, meliputi kemampuan untuk memahami orang lain, apa motivasi mereka, bagaimana mereka bekerja, bagaimana bekerjasama dengan mereka. Assertive, memberikan estimasi terhadap kemampuan terhadap individu untuk mengungkapkan keinginan, pendapat, perasaan dan keyakinan secara langsung, jujur dengan cara-cara yang wajar. Contentment in life, bekerja dengan kepuasan individual dan kebahagian dengan hidup. Resilience, menunjukkan kemam-puan individu untuk bangkit dari kekecewaan, belajar dari kegagalan, dan terus maju, gigih dalam menghadapi kesusahan (kemalangan). Self esteem, menunjukkan perasaan berharga, percaya diri, dan menghormati diri sendiri. Seorang individu dengan self-esteem yang tinggi menganggap memiliki perasaan berharga atas dirinya sendiri. Self actualization, mengukur prestasi potensial individu, tingkat dimana individu percaya bahwa mereka telah merealisasikan potensinya.

\section{Hipotesis Pengaruh Kepemimpinan Transformasional yang Otentik dengan Efek Para Guru dan Karyawannya.}

Penelitian ini menguji 7 hipotesis yaitu pengaruh Kepemimpinan Transformasional Otentik (ATL) dengan Kecerdasan Emosional dengan variabel intervening Kesamaan Value, Kepercayaan, Rasa Kagum. Ketiga variabel tersebut dijadikan variabel antara / intervening berdasarkan pendapat Meglino et al (1989), Kirkpatrick dan Locke (1996), Podsakoff I (1990), Bass (1985) original model, Shamir et al. (1993) yang menyatakan bahwa trust dan value congruence memiliki peran positif dalam proses kepemimpinan. Sedangkan Max Weber menyatakan pentingnya peran reverence (kekaguman) dalam proses kepemimpinan terutama kepemimpinan transformasional yang otentik / karismatik. 


\section{Pengaruh ATL terhadap Value}

Nilai (Value) merupakan keyakinan-keyakinan dasar bahwa suatu modus perilaku atau keadaan akhir dari eksistensi yang khas lebih disukai secara pribadi atau sosial daripada suatu modus perilaku atau keadaan akhir yang berlawanan (Robbins, 2002: 82). Nilai mengandung suatu unsur pertim-bangan dalam arti nilai mengemban gagasan-gagasan seorang individu mengenai apa yang benar, baik atau diinginkan.

Nilai mempunyai atribut baik atribut isi maupun intensitas. Atribut isi mengatakan bahwa suatu modus perilaku atau keadaan akhir eksistensi adalah penting. Atribut intensitas melakukan spesifikasi seberapa pentingkah itu. Bila kita peringkatkan nilai-nilai seorang individu menurut intensitasnya, kita peroleh sistem nilai orang itu.

Umumnya nilai mempengaruhi sikap dan perilaku. Topik tentang value bersama yang dimiliki oleh para pekerja, supervisor, dalam suatu budaya dari suatu organisasi telah diteliti oleh beberapa peneliti dalam bidang organisasi, yang menyatakan bahwa terdapat hubungan yang positif antara tingkat kesesuaian nilai dan performance dari beberapa tingkat dalam organisasi. Avolio dan Gardner (2005) menyatakan bahwa pemimpin dengan ciri transformasional sangat cocok dalam membentuk kesamaan nilai anggota organisasi.

Bawahan akan berusaha menyesuaikan diri dengan nilai-nilai yang dipraktekkan oleh pemimpin secara sukarela karena pemimpin mau mengerti dan berusaha dekat dengan bawahan. Sementara itu, Barling dan Kelloway (2000) menyatakan bahwa kesamaan nilai antara bawahan dengan pemimpin dapat menjadi mediasi antara ATL dengan Kecerdasan Emosional bila tidak terdapat pengaruh antara ATL dengan KE atau bila terdapat pengaruh yang negatif. Barling dan Kelloway (2000) menyatakan bahwa kemampuan memediasi Kesamaan Nilai ini karena ATL mempunyai pengaruh yang signifikan terhadap Kesamaan Nilai bawahan.

\section{H 1 : Kepemimpinan transformasional yang otentik mempengaruhi kesamaan Value para guru dan karyawan.}

\section{Pengaruh ATL terhadap Kepercayaan}

Kepercayaan pada pemimpin merupakan suatu harapan positif bahwa seorang pemimpin tidak akan bertindak secara oportunistik (Robbins, 2002 : 71). Kepercayaan adalah suatu proses ketergantungan historis didasarkan pada sampel-sampel pengalaman yang relevan namun terbatas. Istilah secara oportunistik merujuk pada risiko dan kerentanan yang inheren dalam setiap hubungan kepercayaan. Kepercayaan mencakup hal yang membuat seseorang rentan seperti ketika, misalnya, kita menyingkapkan informasi intim atau bersandar pada janji-janji lain. Karena sifat ini juga, kepercayaan memberikan peluang bagi kekecewaan atau membawa keuntungan. Namun kepercayaan tidak mengandung risiko dari dirinya sendiri, sebaliknya itu merupakan satu keinginan untuk mengambil risiko. Kepercayaan para bawahan terhadap pemimpin merupakan salah satu variabel penting yang dapat menjadi variabel antara dari efektivitas kepemimpinan transformasional (Podsakoff et al. 1990; Yukl, 2002). Tingginya tingkat kepercayaan diantara para pengikut terhadap pemimpin transformasional akan memungkinkan para pemimpin transformasional dan para pengikutnya untuk terus melakukan usaha dan untuk menghadapi rintangan yang menghadang.

H2: Kepemimpinan transformasional yang otentik mempengaruhi Kepercayaan para guru dan karyawan pada kepala sekolah.

\section{Pengaruh ATL terhadap Rasa Kagum}

Pakar sosiologi Max Weber (1925/1968 dikutip dari Conger, et al. 2000) menyatakan bahwa dasar ketertarikan pengikut terhadap pemimpin adalah adanya sebuah persepsi bahwa pemimpin tersebut adalah orang yang luar biasa. Pemimpin karismatik merupakan seseorang yang dianugerahi dengan kekuatan supranatural, manusia super, atau paling tidak kekuatan lebih yang tidak dimiliki oleh orang kebanyakan tetapi dianggap sebagai tauladan dan diperlakukan sebagai seorang pemimpin (Weber, 1968).

Bass \& Avolio (1990) menyatakan bahwa pemimpin yang menjalankan ciri-ciri pemimpin transformasional seperti menunjukkan penghargaan terhadap para bawahan, mampu memahami bawahan, mampu mengestimasi kemampuan bawahan, mampu memberi contoh bagaimana mengatasi hidup, bangkit dari kekecewaan, belajar dari kegagalan, dan terus maju, gigih dalam menghadapi kesusahan (kemalangan) mampu menumbuhkan rasa kagum bawahan.

H3:Kepemimpinan transformasional yang otentik mempengaruhi rasa Kagum para guru dan karyawan.

\section{Pengaruh ATL terhadap Kecer-dasan Emosional}

Barling, Slater dan Kelloway (2000), menemukan bahwa pemimpin dengan kecerdasan emosional yang tinggi akan lebih memilih gaya kepemimpinan 
transformasional. Yong (2003) menyatakan bahwa "para manajer dan pemimpin, secara khusus membutuhkan kecerdasan emosional yang tinggi karena mereka mewakili organisasi kepada publik, mereka berinteraksi dengan banyak orang didalam dan diluar organisasi dan mereka membentuk moral karyawan". Menurut Goleman (1998) kecerdasan emosional merupakan prasyarat bagi kepemimpinan yang sukses, dikarenakan: Pertama, pemimpinlah yang tahu dan dapat mengelola emosinya sendiri, pemimpinlah yang menjalankan kontrol diri dan menunda kepuasan dan mampu menjalankan peran sebagai model bagi para pengikut, dengan demikian menambah kepercayaan dan kehormatan (idealized influence). Kedua, dengan penekanan pada pemahaman emosi orang lain, para pemimpin dengan kecerdasan emosional yang tinggi akan mampu meningkatkan harapan para pengikut, suatu tanda dari inspirational motivation. Ketiga, komponen utama individualized consideration adalah kemampuan untuk memahami kebutuhan-kebutuhan para pengikut dan bergaul dengan mereka secara selaras. Dengan menekankan pada empati dan kemampuan untuk mengelola hubungan yang positif, para pemimpin yang memiliki kecerdasan emosional yang tinggi akan menunjukkan individualized consideration. Sedangkan peneliti lain yang mengkaitkan antara kecerdasan emosional dengan kepemimpinan antara lain: Bass (1985, 1990), Barling dkk. (2000), Krisnan (2005). Goleman (1995: 212) menyatakan bahwa kecerdasan emosional merupakan key success factor bagi seorang pemimpin dan bagi individu dalam kehidupan. Menurut Goleman, Boyatzis dan McKee (2002: 3) para pemimpin besar membangkitkan semangat dan menginspirasi pengikut melalui cara kerja mereka yang melibatkan emosi. Agustian (2001: xxxviii1) dalam Prolognya menyatakan bahwa pengalamannya dalam mempraktekkan gaya kepemimpinan dengan ciri transformasional ternyata meningkatkan kecerdasan emosional bawahannya yang merasa tercerahkan setelah acara "Morning Briefing" yang diadakan 30 menit setiap pagi menjelang dimulainya jam kerja. Materi morning briefing bukanlah masalah-masalah teknis tentang apa dan bagaimana harus bekerja meningkatkan kinerja tetapi hal-hal yang berhubungan dengan komitmen, integritas, berfikir merdeka, visi, arti kerja keras, daya tahan dan kreatifitas. Meskipun materinya tidak berhubungan dengan teknis kerja namun hasil yang dicapai adalah peningkatan kinerja. Hal ini berarti penerapan gaya kepemimpinan transformasional mengakibatkan tumbuh dan berkembangnya kecerdasan emosional dan pada akhirnya meningkatkan kinerja.
H4:Kepemimpinan transformasional yang otentik mempengaruhi Kecerdasan Emosional guru dan karyawan secara langsung

\section{Pengaruh Kesamaan Value terhadap Kecerdasan Emosional.}

Bass (dalam Bass dan Steidlmeier, 1998) menyatakan bahwa kesamaan tata nilai (value) antara pemimpin dengan bawahan tentang apa itu benarsalah, baik-buruk, dan keindahan, mengakibatkan bertambahnya kecerdasan emosional bawahan yang dicirikan oleh tingkat kedewasaan moral yang lebih tinggi. Bahkan kesamaan nilai bisa memediasi hubungan Kepemimpinan Transformasional dengan Kecerdasan Emosional (Siswanto, 2005; Kirkpatrick dan Locke,1996). Allen et al. (2005) menyatakan bahwa kesesuaian nilai antara para pengikut dan budaya organisasi memiliki hubungan yang positif dengan tingkat komitmen para pengikut. Meglino et al. (1989) menjelaskan pengaruh positif value congruence terhadap outcome individual. Mereka menyatakan bahwa individu dengan nilai individu yang sama berusaha untuk membagi berbagai aspek tertentu dan kesamaan tersebut akan membantu adanya komunikasi yang lancar. Ketika nilai para pengikut sesuai dengan nilai dari pemimpin transformasional, mereka diharapkan mengubah motivasinya dari berfokus pada kepentingan sendiri ke fokus kepentingan bersama.

H 5:Kesamaan value mempengaruhi Kecerdasan Emosional guru dan karyawan.

\section{Pengaruh Kepercayaan terhadap Kecerdasan Emosional.}

Kirkpatrick \& Locke (1996), menyatakan bahwa para pemimpin transformasional dapat menggunakan kepercayaan para pengikutnya untuk meningkatkan kecerdasan emosional para pengikutnya dengan menunjukkan kepedulian terhadap kebutuhan para bawahan, menepati janji, menunjukkan kemampuan dan ketekunan untuk mencapai visinya, bersedia berkorban untuk kebaikan organisasi atau group. Avolio \& Gardner (2005) berpendapat bahwa untuk meningkatkan kepercayaan para pengikut dengan cara sering memberdayakan dan memberikan semangat kepada para bawahan untuk membuat keputusan sendiri. Dengan menunjukkan sebagai panutan (a role model) dan menunjukkan penghargaan terhadap para bawahan, pemimpin transformasional juga bisa lebih dikagumi, dihargai dan dipercaya sepanjang waktu (Bass \& Avolio, 1990). 
H6:Kepercayaan pada pemimpin mempengaruhi kecerdasan emosional guru dan karyawan.

\section{Pengaruh Rasa Kagum terhadap Kecerdasan Emosional.}

Persepsi yang muncul dalam pikiran para pengikut yang berupa rasa kagum/kekaguman (reverence) akan dapat mendukung terciptanya suatu rasa menghargai. Sehingga kekaguman akan memperkuat dan mendukung visi inspirasional dari pemimpin dan menyakini bahwa visi tersebut mempunyai makna yang luar biasa. Selama menjalankan visinya, pemimpin akan bertindak sebagai role model yang memberikan contoh pada para pengikut. Rasa kagum tersebut akan menjadi latar belakang peniruan pengikut, jika berhasil mengakibatkan timbulnya kecerdasan emosional pengikut (Goleman, 1998).

H 7 :Rasa kagum mempengaruhi kecerdasan emosional guru dan karyawan.

\section{METODE PENELITIAN}

Skema kerangka konseptual pengaruh Kepemimpinan Transformasional yang otentik terhadap Kecerdasan Emosional adalah seperti terlihat dalam gambar1 .

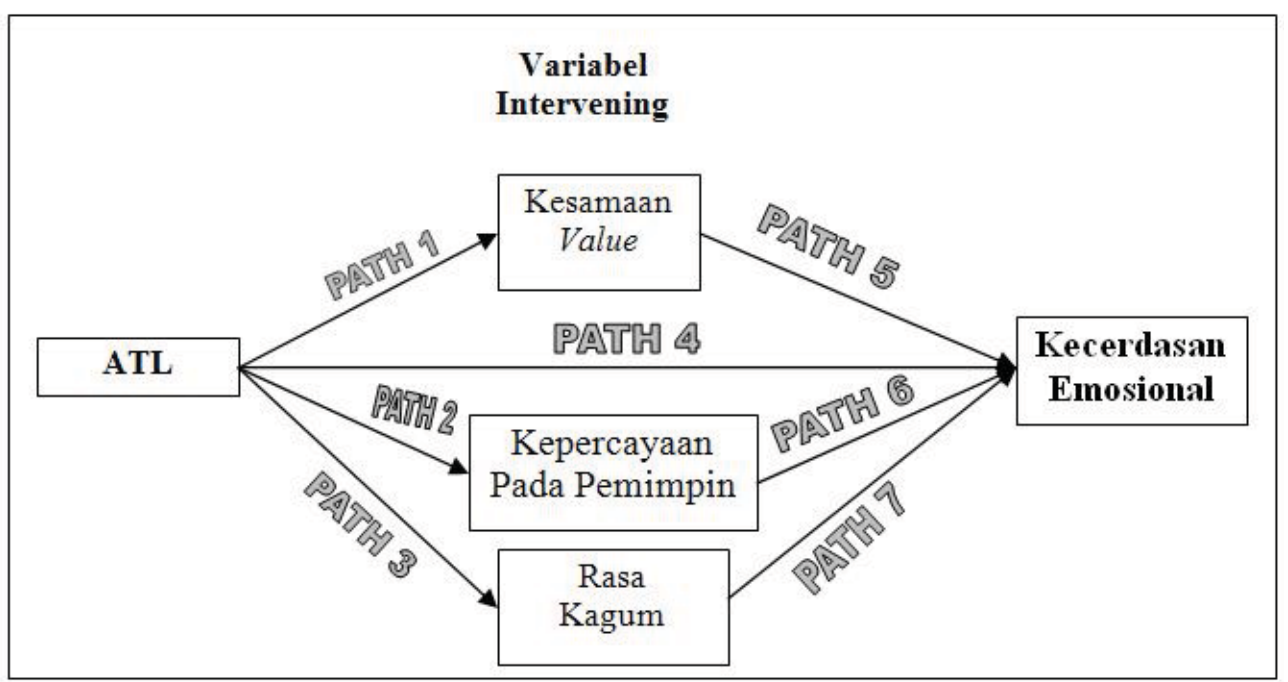

Gambar 1: Model Penelitian

Penelitian ini terdiri atas tiga variabel, yakni variabel bebas, variabel intervening dan variabel terikat. Variabel bebas diwakili oleh Kepemimpinan Transformasional yang Autentik (ATL). Sedangkan variabel intervening yang memediasi antara Kepemimpinan Transformasional yang Autentik dengan Kecerdasan Emosional bawahan terdiri atas: Kesamaan Nilai (Value. Congruence), Kepercayaan pada pemimpin (Trust) dan perasaan kagum pada pemimpin (Rev.). Variabel terikat dalam penelitian ini adalah kecerdasan emosional para bawahan (EQ).

Berdasarkan pokok permasalahan dan hipotesis penelitian yang diajukan, variabel yang akan dianalisis diklasifikasikan ke dalam variabel independen, variabel intervening dan variabel dependen. Variabel independen dalam penelitian ini adalah kepemimpinan transformasional yang otentik (X1) yang dicerminkan dalam empat komponen, yaitu; Idealized influence, Inspirational motivation, Intellectual stimulation, Individualized consideration.
Sementara dalam penelitian ini terdiri atas; kecerdasan emosional(Y). Sedangkan yang bertindak sebagai variabel intervening terdiri atas; value congruence (kesamaan value) (X2), Trust (kepercayaan) (X3), Reverence (rasa kagum)(X4). Untuk mengukur perilaku Kepemimpinan Transformasional yang otentik digunakan kuesioner Multifactor Leadership Questionnaire (MLQ), yang dikembangkan oleh Bass dan Avolio (1985). Sedangkan untuk mengukur variabel intervening (kesamaan value, kepercayaan dan kekaguman) akan dikembangkan suatu instrumen untuk mengukurnya,demikian juga variabel kecerdasan emosional. Oleh karena itu, tiap-tiap instrumen tersebut perlu dilakukan uji validitas dan reliabilitas. Semua instrumen yang digunakan dalam penelitian ini berbentuk cross check dan tanggapan masingmasing pertanyaan diukur dengan menggunakan skala Likert dengan: Angka $1=$ sangat tidak setuju, angka 2 = tidak setuju, angka $3=$ ragu-ragu, angka $4=$ setuju 
dan angka $5=$ sangat setuju. Pengolahan data menggunakan program statistik SPSS (Statistical Package For Social Science) for Windows Release 14.0.

Untuk menguji hipotesis digunakan analisis jalur (Path Analysis), yang bertujuan untuk menguji pengaruh langsung (direct) dan tidak langsung (indirect) variabel kepemimpinan transforma-sional yang otentik terhadap kepuasan pada pemimpin dan kecerdasan emosional dengan variabel intervening; kesamaan nilai antara pemimpin dan para guru dan karyawan, kepercayaan pada pemimpin dan kekaguman pada pemimpin. Agar Analisis jalur (PathAnalysis) dapat memberikan hasil yang konsisten, diperlukan pemeriksaan asumsi dan penerapan theory of trimming (Sarwono 2006:150). Untuk keperluan intepretasi hasil analisis diperlukan perhitungan pengaruh total dari setiap variabel yang mempunyai pengaruh kausal ke variabel endogen (Solimun, 2002 : 44).

Data yang digunakan dalam penelitian ini adalah data primer yang dikumpulkan oleh peneliti dengan penyebaran kuesioner kepada para responden. Populasi dalam penelitian ini adalah para guru dan karyawan sekolah-sekolah Muhammadiyah di Surabaya. Jumlah populasi adalah 422 orang yang terdiri atas guru/karyawan tetap yayasan, guru tidak tetap dan guru DPK. Teknik sampling yang digunakan dalam penelitian ini adalah purposive sampling, yakni teknik pengambilan sampel dengan pertimbangan tertentu. Sampel terdiri atas guru dan karyawan di sekolah-sekolah Muhammadiyah yang berada dibawah penyeleng-garaan Pimpinan Cabang Muhammadiyah Ngagel Surabaya yang terdiri dari 2 Sekolah Dasar (SDM 4 Pucang dan SDM 16 Baratajaya), 1 Sekolah Menengah Pertama (SMPM 5 Pucang) dan 1 Sekolah Menengah Atas (SMAM 2 Pucang).

Besarnya sampel dalam penelitian ini ditetapkan dengan menggunakan tabel penentuan sampel yang dikembangkan oleh Isaac dan Michael (Sugiyono, 2002: 79-81). Dengan tingkat kesalahan 5\% dengan populasi 422 guru dan karyawan, maka ditetapkan jumlah karyawan yang diambil sampel sebesar 191 orang. Data yang digunakan dalam penelitian ini merupakan data primer yang diperoleh secara langsung dari subyek penelitian melalui kuesioner.

\section{HASIL PENELITIAN DAN PEMBAHASAN}

Kuesioner yang dibagikan ke seluruh guru dan karyawan sekolah-sekolah Muhammadiyah di lingkungan PCM Ngagel Surabaya sejumlah 281 buah, 78 di SDM 4 Pucang, 33 di SDM 16 Baratajaya, 55 di SMPM 5 Pucang, dan 115 di SMAM 2 Pucang Surabaya. Kuesioner yang kembali hanya sebanyak 192, namun yang lengkap dan memenuhi syrat hanya sebanyak 191. Oleh karena itu, pada penelitian ini analisis hanya berdasarkan pada 191 kuesionaer saja.

Tabel 1. Respons rate

\begin{tabular}{lccccc}
\hline & SDM 4 & SDM 16 & SMPM 5 & SMAM 2 & JUMLAH \\
\hline Disebar & 78 & 33 & 55 & 115 & 281 \\
Kembali & 47 & 26 & 25 & 94 & 192 \\
\hline Respons rate & $60 \%$ & $79 \%$ & $45 \%$ & $82 \%$ & $68 \%$ \\
\hline
\end{tabular}

Sumber: rekapitulasi pengolahan data

Ditinjau dari aspek demografis, responden paling muda berumur 18 tahun dan yang tertua berumur 60 tahun. Secara lebih rinci jika dikelompokan berdasarkan umur, mayoritas berumur antara 30-35 tahun ada sekitar 26\%, kemudian ada $23 \%$ berumur antara 36-41 tahun. Sementara jika dilihat dari aspek jenis kelamin, distribusi responden laki-laki dan perempuan masing-masing 50\%. Dari 191 responden yang memenuhi syarat dapat mengenai masa kerja mayoritas 5-9 tahun, yakni sebesar $35 \%$. Ada sebanyak 34\% yang memiliki masa kerja di abwah lima tahun. Sementara sisanya, sekitar 21\% memiliki masa 10 tahun atau lebih. Dilihat dari status kepegawaian sebanyak $11 \%$ saya yang berstatus Pegawai negeri Sipil (PNS). Sedangkan sisanya $(89 \%)$ berstatus pegawai yayasan. Dari aspek pendidikan terakhir, ada sebanyak 145 orang atau sekitar $76 \%$ berpendidikan $\mathrm{S} 1$, sedangkan yang berpenddidikan S2 hanya sebanyak 8 orang saja (2\%), responden yang lain berpendidikan di bawah $\mathrm{S} 1$.

Uji validitas atas butir-butir pertanyaan dalam kuisoner yang akan disebar dilakukan pada 30 responden. Hasil uji validitas atas variabel kepemimpinan transformasional yang otentik terdapat 10 item pertanyaan yang tidak valid yakni Q52, Q57, Q70, Q73, Q75, Q77, Q79, Q80, Q84 dan Q86, 
sedangkan 27 item pertanyaan yang lain valid. Item pertanyaan yang tidak valid selanjutnya direvisi. Terdapat 6 item pertanyaan yang valid pada taraf signifikansi 5\% yakni Q56, Q64, Q65, Q67, Q69 dan Q71, sedangkan 21 item pertanyaan sisanya valid pada taraf signifikansi 1\%. Hasil uji validitas instrumen kepercayaan guru dan karyawan menunjukkan semua butir pertanyaan valid pada taraf signifikansi $1 \%$. Demikian pula hasil uji validitas instrumen rasa kagum guru dan karyawan menunjukkan semua butir pertanyaan valid pada taraf signifikansi $1 \%$. Juga hasil uji validitas Instrumen kesamaan value menunjukkan kelima butir pertanyaan valid pada taraf signifikansi 1\%. Instrumen kecerdasan emosional terdiri atas 19 butir pertanyaan. Uji validitas menunjukkan terdapat 3 butir pertanyaan yang tidak valid dan perlu direvisi yakni butir pertanyaan Q37, Q39, Q43. Terdapat 4 butir pertanyaan yang valid pada tingkat signifikansi 5\% yakni butir pertanyaan Q32, Q35, Q36, da Q40, sedangkan sisanya valid pada taraf signifikansi $1 \%$.

Hasil uji reliabilitas, seperti terlihat pada tabel 3, menunjukkan bahwa instrumen yang dipakai reliabel. Variabel kepemimpinan transformasional yang otentik memiliki reliabilitas baik.

Tabel 3 : Uji Reliabilitas Instrumen Penelitian

\begin{tabular}{|c|c|c|c|}
\hline & Variabel & Koefisien Alpha & Keputusan \\
\hline $\begin{array}{l}\text { Variabel } \\
\text { Independen }\end{array}$ & $\begin{array}{l}\text { Kepemimpinan trasforma- } \\
\text { sional yang otentik }\end{array}$ & 0.9211 & Reliabel \\
\hline \multirow[t]{3}{*}{$\begin{array}{l}\text { Variabel } \\
\text { Intervening }\end{array}$} & $\begin{array}{l}\text { Kepercayaan bawahan pada } \\
\text { pemimpin }\end{array}$ & 0.7417 & Reliabel \\
\hline & $\begin{array}{l}\text { Rasa kagum bawahan pada } \\
\text { pemimpin }\end{array}$ & 0.7553 & Reliabel \\
\hline & $\begin{array}{l}\text { Kesamaan value antara } \\
\text { pemimpin dengan bawahan }\end{array}$ & 0.8298 & Reliabel \\
\hline $\begin{array}{l}\text { Variabel } \\
\text { Dependen }\end{array}$ & Kecerdasan emosional & 0.8630 & Reliabel \\
\hline
\end{tabular}

Sumber: Data Primer diolah

Nilai tertinggi variabel kepemimpinan transformasional yang otentik sebesar 5,0 sedangkan nilai terendahnya yaitu $1.0(\mathrm{SD}=0,504)$. Nilai ratarata sebesar 3,847. Variabel intervening, rata-rata tertinggi ditemukan pada kesamaan value yaitu 4,080 $(\mathrm{SD}=0,679)$, rata-rata terendah pada rasa kagum yaitu $4.003(\mathrm{SD}=0,663)$. Rata-rata tertinggi kecerdasan emosional sebesar 3,9725 $(\mathrm{SD}=0,5185)$.

Hipotesis 1 menyatakan bahwa ATL mempengaruhi ValCong para guru dan karyawan, diterima. Dari gambar 4 terlihat bahwa besarnya pengaruh ATL terhadap ValCong adalah 0,638 $(\mathrm{t}$ hitung $=11,396 / \mathrm{sig}=0,000$ ). Hal ini sejalan dengan pendapat Avolio dan Gardner (2005) yang menyatakan bahwa pemimpin transformasional sangat cocok dalam membentuk kesamaan nilai anggota organisasi. Bawahan akan berusaha menyesuaikan diri dengan nilai-nilai yang dipraktekkan oleh pemimpin secara sukarela karena pemimpin mau mengerti dan berusaha dekat dengan bawahan. Sementara itu Barling dan Kelloway (2000) menyatakan bahwa ATL mempunyai pengaruh yang signifikan terhadap Kesamaan Nilai bawahan.

Hipotesis 2 menyatakan bahwa ATL mempengaruhi Trust guru dan karyawan kepada kepala sekolahnya, diterima. Dari gambar 4 menunjukkan besarnya pengaruh ATL terhadap trust 0,634 (t hitung $=11,28 / \mathrm{sig}=0,000$ ). Hal ini sejalan dengan pendapat Podsakoff et al. (1990) yang menyatakan bahwa terdapat pengaruh yang kuat antara kepemimpinan transformasional terhadap kepercayaan. Bawahan akan menaruh kepercayaan kepada pimpinan yang mempraktekkan ciri-ciri pemimpin transformasional seperti mendampingi saat ada kesulitan, menginspirasi dan membantu menemukan solusi kreatif. Demikian pula Yukl (2002) menemukan bahwa kepemimpinan transformasional mempengaruhi kepercayaan bawahan terhadap pemimpin. 
Hipotesis 3 menyatakan bahwa ATL mempengaruhi Reverence, diterima. Dalam gambar 4 menunjukkan besarnya pengaruh ATL terhadap Rasa Kagum adalah 0,689 (t hitung $=13,065 / \mathrm{sig}=0,000$ ). Hal ini sejalan dengan Bass \& Avolio (1990) menyatakan bahwa pemimpin yang menjalankan ciri-ciri pemimpin transformasional seperti menunjukkan penghargaan terhadap para bawahan, mampu memahami bawahan, mampu mengestimasi kemampuan bawahan, mampu memberi contoh bagaimana mengatasi hidup, bangkit dari kekecewaan, belajar dari kegagalan, dan terus maju, gigih dalam menghadapi kesusahan (kemalangan) mampu menumbuhkan rasa kagum bawahan.

Hipotesis 4 menyatakan ATL mempengaruhi EQ guru dan karyawan secara langsung, diterima. Keempat variabel independen secara simultan mempengaruhi kecerdasan emosional sebesar 0,587 karena nilai $F$ hitung sebesar 65,983 dengan signifikansi $0,000(\mathrm{P}<5 \%)$. Secara parsial ATL mempengaruhi EQ sebesar 0,612 valid karena nilait hitung sebesar 8,475 $(\mathrm{p}=0,000 / \mathrm{p}<5 \%)$. Ini sejalan dengan pendapat Barling, Slater dan Kelloway (2000), menemukan bahwa pemimpin dengan kecerdasan emosional yang tinggi akan lebih memilih gaya kepemimpinan transformasional. Yong (2003) menyatakan bahwa para manajer dan pemimpin, secara khusus membutuhkan kecerdasan emosional yang tinggi karena mereka mewakili organisasi kepada publik, mereka berinteraksi dengan banyak orang didalam dan diluar organisasi dan mereka membentuk moral karyawan. Hasil penelitian ini tidak sejalan dengan penelitian Siswanto (2005) yang menemukan bahwa tidak terdapat pengaruh langsung antara ATL dengan Kecerdasan Emosional. Goleman (1998) juga mengatakan bahwa kecerdasan emosional merupakan prasyarat bagi kepemimpinan yang sukses, artinya bila ATL tidak berpengaruh secara langsung terhadap kecerdasan emosional bisa dicari variabel mediasi yang berpengaruh positif terhadap kecerdasan emosional.

Hipotesis 5 menyatakan bahwa kesamaan value mempengaruhi Kecerdasan Emosional Guru dan karyawan, diterima. Besarnya pengaruh 0,438 adalah valid, karena thitung sebesar $6,778(\mathrm{p}=0,000 / \mathrm{p}<5 \%)$. Hal ini sejalan dengan Meglino et al. (1989) bahwa terdapat pengaruh positif value congruence terhadap outcome individual. Demikian halnya Allen et al. (2005) yang menyatakan bahwa kesesuaian nilai antara para pengikut dan budaya organisasi memiliki hubungan yang positif dengan tingkat komitmen para pengikut.

Hipotesis 6 menyatakan bahwa Kepercayaan pada pemimpin mempengaruhi kecerdasan emosional guru dan karyawan, ditolak. Besarnya pengaruh - 0,146 adalah valid, karena thitung sebesar -2,018 dengan signifikansi $0,045(\mathrm{p}<5 \%)$. Hasil ini berbeda dengan penelitian Kirkpatrick \& Locke (1996) yang menemukan pengaruh positif antara kepercayaan dengan kecerdasan emosional. Hasil penelitian ini juga berbeda dengan temuan Avolio \& Gardner (2005) yang berpendapat bahwa, untuk meningkatkan kepercayaan para pengikut dengan cara sering memberdayakan dan memberikan semangat kepada para bawahan untuk membuat keputusan sendiri dapat meningkatkan kecerdasan emosional.

Hipotesis 7 menyatakan bahwa rasa kagum mempengaruhi kecerdasan emosional guru dan karyawan, ditolak. Besarnya pengaruh $-0,165$ adalah valid, karena memiliki t hitung sebesar -2,066 dengan signifikansi 0,040 $(\mathrm{P}<5 \%)$. Hasil penelitian ini berbeda dengan temuan Goleman (1998) yang menyatakan bahwa persepsi yang muncul dalam pikiran para pengikut yang berupa rasa kagum/ kekaguman (reverence) akan dapat mendukung terciptanya kecerdasan emosional yang berupa meningkatnya rasa menghargai dalam bentuk memperkuat dan mendukung visi inspirasional dari pemimpin dan menyakini bahwa visi tersebut mempunyai makna yang luar biasa. Secara ringkas dapat digambarkan pada gambar 4 .

Hasil penelitian menunjukkan dari tujuh hipotesis yang ditetapkan ternyata hubungan pengaruh variabel yang dikemukakan dalam hipotesis sebanyak lima hipotesis $(\mathrm{H} 1, \mathrm{H} 2, \mathrm{H} 3, \mathrm{H} 4$, dan $\mathrm{H} 5)$ mempunyai taraf signifikansi sangat kuat (dibawah 1\%), sedangkan dua hipotesis (H6 dan H7) mempunyai taraf signifikansi kuat yaitu dibawah 5\%. Penelitian ini juga menunjukkan bahwa dari tujuh hipotesis yang ditetapkan ternyata sebanyak lima hipotesis (H1, H2, H3, H4, dan H5) diterima karena mempunyai pengaruh yang positif, sedangkan dua hipotesis (H6 dan H7) ditolak. Dua hipotesis ditolak karena menunjukkan pengaruh negatif. Besaran pengaruh negatif menjadikan penolakan hipotesis yang mensyaratkan besaran pengaruh positif.

Hal ini menunjukkan bahwa Kepemimpinan Transformasional yang Otentik mempunyai pengaruh positif terhadap Kecerdasan Emosional secara langsung. Hasil penelitian ini sejalan dengan Meglino (1989), Kirkpatrick dan Locke (1996), Podsakoff et al. (1990), Bass (1985) original model dan Shamir et al (1993). Hasil penelitian ini tidak sejalan dengan penelitian Siswanto (2005) yang menyatakan bahwa Kepemimpinan Transformasional yang Otentik tidak bisa secara langsung mempengaruhi Kecerdasan Emosional guru dan karyawan Madarasah Aliyah di Jombang sehingga harus dimediasi oleh variabel intervening. 


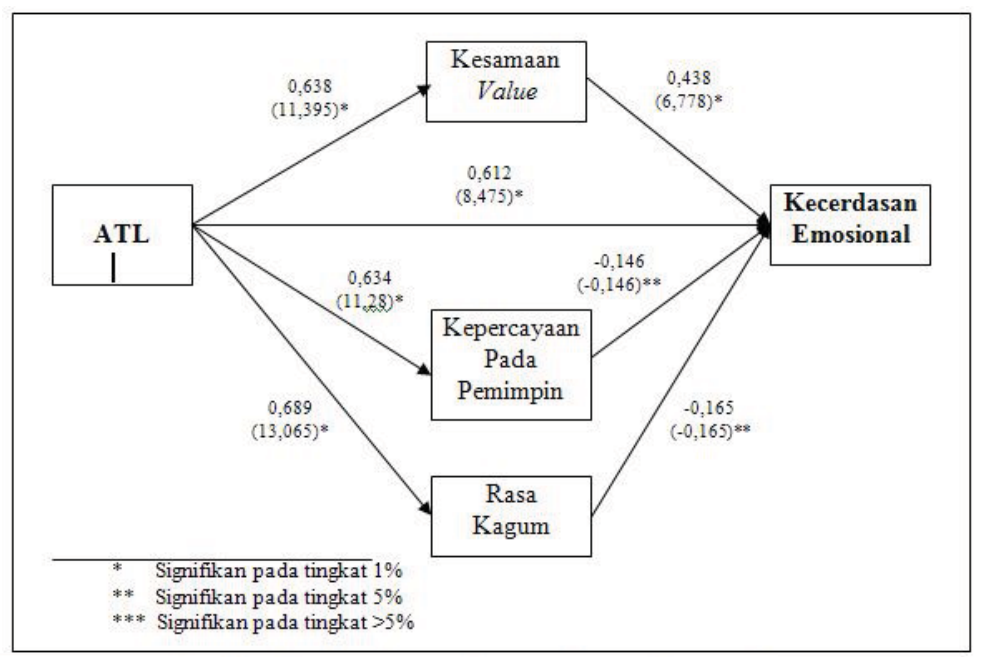

Gambar 4. Analisis Jalur Pengaruh ATL terhadap Kecerdasan Emosional

Salah satu penyebab perbedaannya adalah bahwa proses pemilihan kepala sekolah di sekolah-sekolah Muhammadiyah yang diteliti ternyata berjalan lebih demokratis, lebih transparan dan lebih melibatkan guru dan karyawan dibanding di Madarasah Aliyah Jombang. Selain itu Yayasan (dalam hal ini Majlis Dikdasmen) hanya menetapkan dan melantik kepala sekolah yang mendapat skor tertinggi (termasuk suara terbanyak). Proses seleksi calon kepala sekolah dimulai saat pengajuan calon oleh guru dan karyawan saat penjaringan bakal calon. Yang selanjutnya akan disaring dengan persyaratan administratif yang telah ditetapkan Majlis Dikdasmen. Hanya bakal calon yang memenuhi syarat administratiflah yang berhak mengikuti proses "fit and proper test" yang diselenggarakan oleh Majlis Dikdasmen. Hasil dari "fit and proper test" berupa calon kepala sekolah (biasanya berjumlah 3 orang) yang siap dipilih oleh Dewan Guru sebagai representasi guru dan karyawan.

Hasil penelitian juga menunjukkan bahwa pengaruh Kepemimpinan Transformasional yang Otentik terhadap Kecerdasan Emosional dimediasi oleh faktor intervening berupa Kesamaan Value, Kepercayaan pada Pemimpin, dan Rasa Kagum. Namun variabel Kepercayaan pada Pemimpin dan variabel Rasa Kagum bernilai negatif dalam mempengaruhi Kecerdasan Emosional guru dan karyawan. Pengaruh yang negatif ini mengisyaratkan bahwa tindakan pemimpin yang berusaha memupuk atau mencari kepercayaan dari bawahan ternyata malah berdampak negatif terhadap kecerdasan emosional. Bawahan malah menganggap tindakan pemimpin yang berusaha mendapat, memupuk bahkan mencuri kepercayaan adalah sesuatu yang negatif dan dinilai sebagai suatu pertanda bahwa pemimpin kurang percaya diri, tidak mampu membuktikan kinerja indi- vidual pemimpin sehingga para guru dan karyawan justru menganggap kepala sekolah telah berbuat naif yang pada akhirnya akan menurunkan kecerdasan emosional guru dan karyawan.

Para guru dan karyawan juga memandang upayaupaya kepala sekolah yang berusaha menimbulkan dan/ atau meningkatkan rasa kagum guru dan karyawan terhadap kepala sekolah baik yang dilakukan sendiri oleh kepala sekolah maupun melalui perangkat organisasi yang dikuasai oleh kepala sekolah justru akan mengurangi rasa hormat dan justru akan menimbulkan perasaan was-was dan prasangka buruk yang pada akhirnya akan berakibat pada penurunan kecerdasan emosional. Guru dan karyawan lebih senang kalau prestasi dan kelebihan yang dimiliki kepala sekolah tidak di cerita-ceritakan atau di tonjol-tonjolkan oleh kepala sekolah. Karena upaya penonjolan prestasi kepala sekolah secara sengaja akan dinilai sebagai upaya pamer (riya'), meminta pamrih, dan tanda ketidak ikhlasan kepala sekolah dan hal ini berujung pada penurunan kecerdasan emosional guru dan karyawan.

Negatifnya keefektifan mediasi variabel Kepercayaan pada Pemimpin dan Rasa kagum guru dan karyawan kepada Kepala Sekolah dalam penelitian ini tidak sejalan dengan penelitian Podsakoff et al. (1990) dan Yukl (2002). Negatifnya variabel Kepercayaan pada Pemimpin mungkin disebabkan oleh sifat homogen dari guru dan karyawan dengan pemimpinnya. Mereka semua berangkat dari ideologi perjuangan yang sama yaitu Muhammadiyah sehingga tidak diperlukan lagi kepercayaan yang harus dibangun khusus oleh pemimpin. Para guru dan karyawan sudah yakin dan percaya bahwa seluruh guru dan karyawan yang bekerja di sekolah-sekolah Muhammadiyah telah melewati seleksi yang ketat 
oleh Majlis Dikdasmen sehingga tidak perlu diragukan lagi. Sedangkan negatifnya variabel Rasa Kagum dalam memediasi Kepemimpinan Transformasional yang Otentik terhadap Kecerdasan Emosional guru dan karyawan mungkin disebabkan oleh kentalnya suasana egaliter yang dibangun di sekolah-sekolah Muhammadiyah yang diteliti. Suasana kebersamaan baik saat perencanaan (misalnya dalam penyusunan dan pembuatan Rencana Anggaran Pendapatan dan Belanja Sekolah-RAPBS), perngorganisasian, pelaksanaan dan evaluasi setiap kegiatan dilakukan secara bersama sesuai dengan peran dan fungsi masing-masing. Jadi kemenonjolan aktivitas dan kepribadian guru dan karyawan adalah berdasarkan peran dan fungsinya. Selain itu, mereka semua adalah sama derajat, hak dan kewajibannya.

Penelitian ini mempunyai keterbatasan yaitu beberapa instrumen yang digunakan berupa instrumen baku, sehingga kemungkinan terdapat kesalahan dalam menterjemahkan instrumen tersebut, yang akhirnya mempengaruhi persepsi guru dan karyawan. Selain itu analisis terhadap Sekolah Dasar dan Sekolah Menengah masih digabung, padahal perbedaan karakteristik sekolah tersebut memungkinkan perbedaan hasil penelitian. Selain itu semua obyek penelitian tergolong dalam sekolah unggulan di Surabaya, diperlukan judgement khusus untuk keperluan generalisasi.

\section{SIMPULAN}

Berdasar pembahasan di atas dapat ditarik suatu simpulan bahwa untuk menghindari gaya kepemimpinan yang laissez-faire yang cenderung membiarkan kepala sekolah berbuat apa saja tanpa kontrol yang terukur seperti halnya pada pola kepemimpinan sosial yang pada umumnya terjadi pada persyarikatan, induk organisasi yang menaungi dan memiliki sekolah-sekolah Muhammadiyah, diperlukan penerapan pola kepemimpinan transformasional. Kepemimpinan tersebut mencakup ciri-ciri pemimpin transformasional seperti menunjukkan penghargaan terhadap para bawahan, mampu memahami bawahan, mampu mengestimasi kemampuan bawahan, mampu memberi contoh bagaimana mengatasi hidup, bangkit dari kekecewaan, belajar dari kegagalan, dan terus maju, gigih dalam menghadapi kesusahan (kemalangan) mampu menumbuhkan rasa kagum bawahan.

\section{DAFTAR PUSTAKA}

, Suara Muhammadiyah. 2004. Edisi 14.

Agustian, Ary Ginanjar. 2001. ESQ, Rahasia Sukses Membangun Kecerdasan Emosi dan Spriritual Berdasarkan 6 Rukun Iman da 5 Rukun Islam, Penerbit Arga, Bandung.

Allen, Malcolm and Elizabeth Harrison. 2005. Enabling and Empowering Authentic Transformational Leaders, Authentic Transformational Leadership Institute, New York.

Avolio, Bruce J. and William L Gardner. 2005. Authentic Leadership Development: Getting to the root of positive forms of leadership, Gallup Leadership Institute, Nebraska.

Barling, J., Slater F \& Kelloway E.K. 2000. Transformational Leadership and Emotional Intelligent: An Exploratory Study, Leadership \& Organizational Development Journal, Vol.21 No.3,pp 157-161.

Bar-On, R., Parker J.D.A.(Eds.) 2000. The Handbook of Emotional Intelligence: Theory, Development, Assesment, and Application at home, school and in the workplace, San Fransisco: Jossey-Bass.

Bass, Bernard M. 1985. Leadership \& Performance Beyond Expectations, New York: Free Press.

Bass, Bernard M. 1990. From Transactional to Transfor-mational Leadership: Lear-ning to share a Vision. Organizational Dynamics, 18(3), pp. 19-31.

Bass, Bernard M., and Bruce J Avolio. 1990. Manual for the Multifactor Leadership Questionnaire, Palo Alto, CA: Consulting Psychologist Press.

Bass, Bernard M., and Paul Steidmeier. 1998. Ethics, Character, and Authentic Transformational Leadership (electronic version), Leadership Quarterly, 10(2), 181-218. Available from http:/ /cls.-binghamton.edu/BassSteid. html.

Conger, J. \& Kanungo, R.N. 1988. Charismatic Leadership: The elusive factor in organizational effectiveness. San Francisco: Jossey-Bass.

Goleman. 1995. Emotional Intel-ligence, London: Bloom-sbury.

Goleman. 1998. Working with Emotional Intelligence, New York: Bantam.

Goleman, D. Annie McKee, Richard E..Boyatzis.. 2002. Primal Leadership: Realizing the Power of Emotional Intelligence. Boston: Harvard Business School Press. 
Hsu, Wei-Ling, Bor-Shiuan Cheng, Min-Ping Huang, and Jiing-Li Farh. 2005. Moral Leadership in Taiwanese Organizations: Developing the Construct and the Measurement, Department of Psychology National Taiwan University. Available from d88227001@ms88.ntu.edu.tw, $24 \mathrm{pp}$

Kezar, Adrianna. 2004. Philosophy, Leadership, Scholarship: Confucian Contributions to a Leadership Debate, Leadership Review, Vol. 4, Fall pp. 110-131.

Kirkpatrick, S.A. and Locke, E.A. 1996. Direct and Indirect Effect of three core charismatic leadership component on performance and attitudes, Journal of Applied Psychology, Vol. 81 No.1 pp. 36-51.

Krisnan, Venkat R. 2005. Leader-Member Exchange, Transformational Leadership, and Value System, Electronic Journal of Business Ethics and Organization Studies 10 (1): 14-21.

Meglino, B.M, Ravlin E.C., and Adkins C.L. 1989. A work values approach to corporate culture: A field test of the value congruence process and its relationship to individual outcomes, Journal of Applied Psychology, Vol. 22 No. 1 pp. 424432.

Mujtahid, 2011, http://www.uin-alang.ac.id/index.php diakses tanggal 16 Maret 2011

Podsakoff, P.M., Niehoff, B.P., Moorman, R.H. \& Fetter, R. 1990. Transformational leader behaviors and their effects on followers' trust in leader, satisfaction, and organizational citizen beha-viors. Leadership Quarterly, 1, 107-142.

Robbins, Stephen P. 2003. Organi-zational Behavior. Edisi bahasa Indonesia. Penerbit PT INDEKS kelompok Gramedia, Jakarta.

Salovey, P., Mayer, JD. 1990. Emotional Intelligence: Imagination, Cognition, and Personality, 9, 185221.

Sarwono, Jonathan. 2006. Analisis Data Penelitian Menggu-nakan SPSS 13. Penerbit Andi, Yogyakarta.

Shamir, B., House, R.J. \& Arthur, M.B. 1993. The motivational effects charismatic leaders: A s elf-concept based theory. Organizational Science, 4, 577-594.

Siswanto. 2005. Pengaruh Authen-tical Transformational Leadership terhadap Kepu-asan Kerja Guru dan Karyawan Madarasah Ali-yah di Surabaya, Dise-rtasi Universitas Airlangga Sura-baya.
Solimun. 2002. SEM, LISREL, AMOS. Penerbit UNM, Malang.

Sudibyo, Bambang. 2006. Renstra Departemen Pendidikan Nasional dan Perbandingan kinerja Pendidikan antar Provinsi, Makalah Menteri Pendidikan Nasional pada Rapat Kerja Nasional Majlis Pendidikan Dasar dan Menengah Muhammadiyah, Juni, Jakarta.

Sugiyono. 2002. Metode Penelitian Bisnis, CV Alfabeta, Bandung.

Suyanto. 2006. Pendidikan Muham-madiyah dalam Konteks Pendidikan Nasional, Maka-lah Rapat Kerja Nasional Majlis Pendidikan Dasar dan Menengah Muham-madiyah, Juni, Jakarta.

Yong, Leonard. 2003. Yong EQ Inventory: Norm \& Technical Manual, Kuala Lumpur: LPI Sdn Bhd. www.leonard.com.my.

Yukl, Gary. 2002. Leadership in Organizations, Prentice-Hall Inc., New Jersey.

Yusuf, M.Yunan. 2004. Pemikiran kearah Amandemen Qaidah Majlis dan Qaidah Pendi-dikan serta Perumusan Ke-unggulan Pendidikan Dasar dan Menengah Muham-madiyah, Makalah Rapat Kerja Nasional Majlis Pendidikan Dasar dan Menengah Muhammadiyah, Juni, Jakarta. 